\title{
The "Belt \& Road" Initiative and Its Chinese Traditional Philosophical Root
}

\author{
ZHANG Wentao \\ Northwestern Polytechnical University, Xi'an, China
}

\begin{abstract}
This article analyzes the relations between Chinese traditional philosophy and the "Belt \& Road" Initiative. The idea of "Belt \& Road" Initiative has a deep root in Chinese traditional philosophy. Silk Road has become a symbol of peace and friendship in Chinese culture and it always brings back the good memories in Chinese people about the prosperity of trade and economy. The both Silk Roads not only witnessed the exchange and communication between China and western areas to China, but also the most prosperous time in Chinese history. China proposes the "Belt \& Road" Initiative with the purpose of constructing a more prosperous world by the jointing efforts of the nations all over the world. Because of the barriers and misconceptions in transcultural and cross-cultural activities, people from different cultures have difficulty in understanding the "Belt \& Road" Initiative with its founding meanings. This paper aims to offer clear image about the background, context, and core points of the "Belt \& Road" Initiative. In fact, the "Belt \& Road" Initiative is natural reflection of Chinese traditional philosophy. If the essence of Chinese traditional philosophy, for example, "harmony but diversity", the "peace and war" as well as the balance of "Yin" and "Yang" could be understood well, it would be much easier to have a correct understanding about the concept of the "Belt \& Road" Initiative.
\end{abstract}

Keywords: Belt \& Road, initiative, Chinese philosophy

The "Belt \& Road" initiative was put up with by Chinese government in the year of 2013. Then a series of policies and measures were introduced to support this initiative. In November 2014, China invested $\$ 40$ billion to set up the "Silk Road Fund". The major function of the fund was stated as "it is designed to promote common development and prosperity of China and other countries and regions involved in the Belt \& Road Initiative" . In January 2016, 57 countries signed the Articles of Agreement of Asian Infrastructure Investment Bank (AIIB) in Beijing, which symbolized the official operation of AIIB. Together with the Summit of the "Belt \& Road" Initiative as well as the launch of several economic corridors in the frame of the "Belt \& Road" Initiative, the "Belt $\&$ Road" has become a very popular and heated term all over the world.

The emergency of the "Belt \& Road" Initiative aroused great interest of scholars in the field of diplomatic relations, international politics, and other relevant fields. There are many studies on this topic from different perspectives. This article studies the origin of philosophical thought from Chinese cultural perspective to reveal the core idea of "Belt and Road" Initiative which is the reflection of Chinese ancient philosophy. And at the same time, by interrelating the initiative and Chinese classic philosophical thought, the author hopes to give a

ZHANG Wentao, Dr., executive dean of the School of Foreign Studies, Northwestern Polytechnical University, Xi'an, China.

1 "Silk Road Fund", accessed 23rd Dec. 2018, http://www.silkroadfund.com.cn/enweb/23775/23767/index.html. 
deeper explanation of Chinese culture.

\section{The Relationship Between "Belt \& Road" Initiative and the Ancient Silk Road}

On the 7th September, 2013 when Chinese president Xi Jinping visited the Republic of Kazakhstan, he delivered in his speech that China was willing to construct the Silk Road Economic Belt together with the countries along the Ancient Silk Road. On the 3rd October of the same year, he expressed the idea to construct the 21st century Maritime Silk Road with ASEAN countries when he was invited to deliver a speech at Indonesian congress. Then the "Silk Road Economic Belt" and the "21st century Maritime Silk Road" were abbreviated as the "Belt \& Road" Initiative. Starting from Chinese mainland, there was a strong heat wave seeping the whole country and people in all walks of life started to turn their attention to the "Belt \& Road" Initiative.

\section{The Silk Roads in Ancient China}

The Ancient Silk Road refers to a trade route connecting China and Mediterranean in history. This route was started in Chinese Han Dynasty (202 B.C-220 A.D). Emperor Wu Di, the 4th emperor of Han Dynasty, sent his envoy to look for the partnership and the commercial cooperation to the west of China. According to Historical Records, a famous Chinese ancient book of history, the envoy called Zhang Qian left Chang'an (now the city of Xi'an), the capital city of Han Dynasty in 138 B.C for Da Rou Chi, which was believed the name of Great Rose in Chinese language. Historical Records noted that because of the invasion of Huns, one of minorities to the north of Han Dynasty, the emperor of Han Dynasty hoped to have the support from Da Rou Chi. Zhang Qian was sent to west regions as the envoy of the Han's emperor twice. It was a pity that he didn't persuade any tribes or minorities successfully to ally with Han Dynasty, but he brought back a lot of items or merchandize including horses, saddles, iron wares, carrots, and etc., from the regions along his voyage, which in fact set the milestone for the trade between Han Dynasty and regions in the west regions to Han Dynasty. Therefore, Zhang Qian was regarded as the inaugurator of the Ancient Silk Road. The Ancient Silk Road was most flourished from 138 B.C to 1453 A.D. In 1453, when the Ottoman Empire occupied the middle and Western Asian, it cut off the trade line between the east and the west. The Ancient Silk Road became declined and withered away from the history. It was until 1877 that a German geographer, Ferdinand von Richthofen (1883, p. 57), used the term "Silk Road" for the first time to refer to Chinese Ancient Silk road which was marked by the red line in Figure 1. 


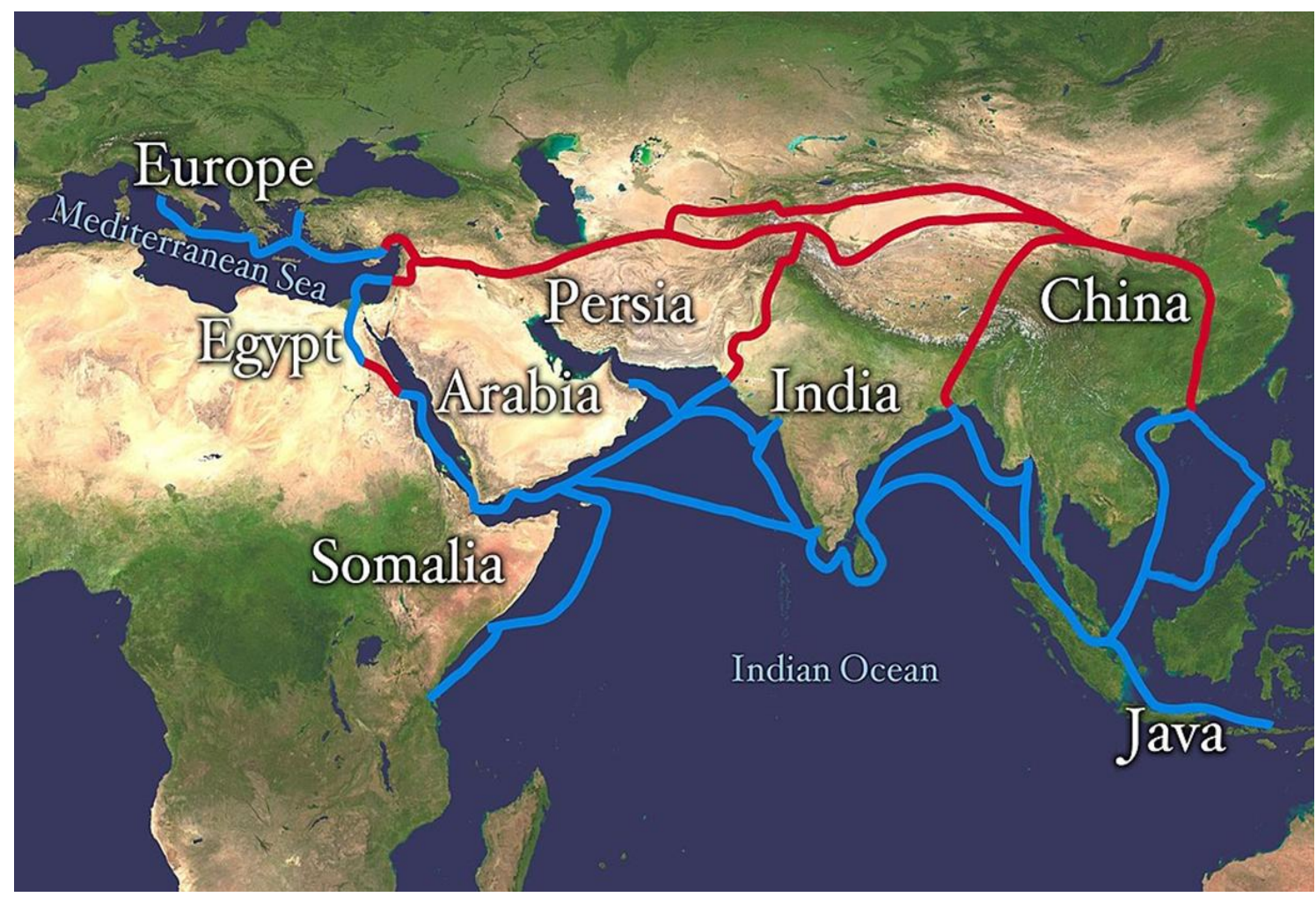

Figure 1. Red: Ancient Silk Road; Blue: Maritime Silk Road.

In Chinese history, there was another silk road, which is called Maritime Silk Road. The term "Maritime Silk Road" was first used by Emmanuel-èdouard Chavannes, an eminent French scholar in 1913 (p. 18). It is not difficult to understand that the Maritime Silk Road emerged later than the Silk Road on land, because the transportation on the sea relies more on the technology of ship building. In the 6th century, progress in ship building and in seamanship made it possible to have a far ocean voyage. In the 8th century, a Chinese monk named Jian Zhen made at least six trips from China to Japan. In the meantime, Japan sent seven delegations to China. The frequent mutual visits were attributed to the great ship which could be built in that time. The compasses were also used in navigation during that time. In Chinese Song Dynasty (960 A.D-1279 A.D), in the marine trade, the earlies anti-smuggling law, which was called Lou Bo Law was even found in that time. Lou Bo Law, if translated literally, means law about the (merchandize) Leaking (Lou) from Shipping (Bo). The most well-known event about the Maritime Silk Road is about Zheng He, a eunuch of Ming Dynasty (1368-1544) who made seven voyages to coastal area of Southeast Asia, Indian Ocean, the Red Sea, and Mediterranean.

\section{The Implication of Silk Roads in Chinese Culture}

Even if the names of both Silk Road and Maritime Silk Road were not given by Chinese people, all Chinese people had regarded Silk Road as the symbol of Chinese culture. In the June of 2014, UNESCO declared that the Silk Road from the city of Chang'an (now the city of Xi'an) to Tian Shan Mountain, which is located on the border of northwest China to Kazakhstan, was listed in the World Cultural Heritages. As for the reason that the Silk Road takes a very special position in Chinese culture, it is necessary to have a close examination on the influence of the Silk Road on Chinese people's lives. 
Firstly, a large amount of merchandize was exchanged along the Ancient Silk Road or the Maritime Silk Road. Most of these items are still in use even in today's Chinese people's daily lives. Some traces could be discovered in today's Chinese language, for example, the carrot, which is called "Hu Luo Bo" in Chinese language, was the vegetable introduced from the Ancient Silk Road. "Hu" in Chinese language means the areas or people to northwest of China. Another example is the pepper, which is called "Hu Jiao" in Chinese language. Both carrot and pepper have the word "Hu" if pronounced in Chinese language. Similarly, "matches" in Chinese language used to be called "Yang Huo", in which "Yang" means "ocean", and "Huo" means "fire". It meant that such fire was introduces from the ocean out of China. There are some more examples in Chinese language. For example, the "onion" till today is stilled called "Yang Cong", in which "Yang" also means "ocean", and "Cong" refers to a vegetable. It is evident that those items with "Hu" were introduced from the Ancient Silk Road, while the items with "Yang" originated from abroad, mostly transported from the Maritime Silk Road.

Secondly, the most flourishing time of the Ancient Silk Road was from 2nd century B.C to 15th century A.D. This period of time was the most prosperous duration in Chinese ancient history. Some examples could reflect how great the influence of this duration is on Chinese culture. The time from 2nd century B.C to 3rd century A.D was Chinese Han Dynasty (202 B.C-220 A.D) when the Ancient Silk Road was explored. Today, China writing words are still called "Han Zi", which means the characters in Han Dynasty or for Han people. Today, there are 56 ethnic groups in China. According to the population of different ethnics, the major group is "Han". According to Chinese National Bureau of Statistics, the population of the ethnic group Han has reached 1.22 billion $^{2}$, accounting for $14 \%$ of world population. Most importantly, all these people have the identity recognition that they belong to the ethnic group of Han. Another case is the Tang Dynasty which lasted from 618 A.D to 907 A.D. Tang Dynasty is regarded the most wealthy and powerful duration in Chinese ancient history. In Tang Dynasty, the trade on the Silk Road was very flouring and the nations in the West Asia regions were recorded in Tang's achieves (Liu et al., 2018, pp. 51520-51541). Umayyad Caliphate (أموي ون, Tay in Persian) was called Da Yi in White by people in Tang Dynasty. The Abbasids Empire (العبّاسيّون) was called Da Yi in Black. In Chinese historical books, there were many descriptions about the exchange between China and the nations in Arabian regions. No matter whether it is Han Dynasty or Tang Dynasty, the Silk Road seemed to be flourishing always when China was in its most prosperous periods. Therefore, when Chinese new leader and new government were elected in China in the end of 2013 and early of 2014, it was natural that the new government came up with the "Belt \& Road" Initiative, for it was intended to bring all Chinese back to their glorious time in history. This was also coincided with the "Chinese Dream", which took the restoration of Chinese nation as its core.

\section{The Silk Road, Whether on Land or on the Sea, Represents Opening Up and Cooperation}

Ancient Silk Road was not an enclosed road. It was an open road. It used to play a role in connecting those countries which would like to develop commercial relationship and friendship with China. It is hoped to have the same function today. In August of 2006, China, Kazakhstan, Kyrgyzstan, Uzbekistan, and Tajikistan decided to jointly submit application to UNESCO for the Silk Road listed as world heritage. Because of the changing policy of UNESCO, only one part (the distance from the city of Chang'an, the city of Xi'an now, to Tian Shan Mountains) was approved by UNESCO in June of 2014. The Silk Road belongs to the whole world.

\footnotetext{
${ }^{2}$ Idex, accessed 25th Dec. 2018, http://www.stats.gov.cn/tjsj/pcsj/rkpc/6rp/indexch.htm.
} 
It is the crystal of civilization for whole human beings.

In addition, with the fast development of Chinese economy in recent 40 years, China has accumulated large amount of manufacturing abilities. In the meantime, there is a great demand for manufacturing in those less developed areas. Comparatively, West Asia, Southeast Asia, and Africa are surely more potential to have the cooperation with China in manufacturing. These areas are geographically located along the Ancient Silk Road or Maritime Silk Road. This is believed another reason that China proposed the "Belt \& Road" Initiative.

\section{Main Points of the "Belt \& Road" Initiative}

Ever since the "Belt \& Road" Initiative was launched in 2013, China has put up with a series of policies and measures to push the operation of the initiative. In December 2014, the "Silk Road Fund" was set up to support the construction of infrastructures along the Silk Road Economic Belt. The original investment for this fund was $\$ 4$ billion. In the May of 2017, Chinese government added extra RMB 10 billion. In March of 2015, China publicized the Vision and Actions on Jointly Building Silk Road Economic Belt and 21st-Century Maritime Silk Road, which figured out the "Five Goals" to realize the "Belt \& Road" Initiative. The "Five Goals" are "policy co-ordination, facilities connectivity, unimpeded trade, financial integration, people-to-people bonds" among the countries who joined in the initiative. In the Summit Conference of "Belt \& Road" held in Beijing in the May of 2017, China declared that the modern Silk Roads which contain the Silk Road Economic Belt and the Maritime Silk Road were expected to be constructed as the road for peace, road for prosperity, road of opening up, road of innovation, road connecting different civilizations.

In order to provide a solid support to the initiative, Asian Infrastructural Investment Bank (AIIB) sponsored by China was set up in December of 2015. The bank attracted the attention of the whole world immediately. AIIB offers sovereign and non-sovereign financing for sound and sustainable projects in energy and power, transportation and telecommunications, rural infrastructure and agriculture development, water supply and sanitation, environmental protection, urban development and logistics. The number of the founding members of AIIB was 57 and till the end of 2018, the number of members has reached 93. AIIB makes the "Belt \& Road" Initiative become more substantial and visualized.

On the basis of a series of policies and measures, six mature cooperation areas became more prominent. These six areas were named "corridors", which included: the New Eurasia Land Bridge Economic Corridor, on which there were regular scheduled trains from the east coastal city of Lian Yun Gang Harbor to the Rotterdam, north tip of the Netherlands; The China-Mongolia-Russia Economic Corridor; China-Central Asia-West Asia Economic Corridor; China-Indochina Peninsula Economic Corridor; China-Pakistan Economic Corridor; and Bangladesh-China-India-Myanmar Economic Corridor. It is easy to see that the major contents of the activities in these corridors are economic co-operations. Among the six corridors, four of them are based on the Silk Road Economic Belt and the other two are centered on the 21st Maritime Silk Road. The following table shows the basic conditions of the six corridors: 
Table 1

Basic Information of the Six Economic Corridors

\begin{tabular}{|c|c|c|c|c|}
\hline No. & Title & Time & Newest development & Main contents \\
\hline 1 & $\begin{array}{l}\text { The New Eurasia Land Bridge } \\
\text { Economic Corridor }\end{array}$ & 1992 & $\begin{array}{l}\text { Till Dec. 2018, the number of trains entitled } \\
\text { with China Railway Express has been more than } \\
11,000, \text { reaching } 44 \text { cities of } 15 \text { countries in } \\
\text { Europe }^{3} \text {. }\end{array}$ & $\begin{array}{l}\text { Railway transportation, } \\
\text { infrastructure connectivity. }\end{array}$ \\
\hline 2 & $\begin{array}{l}\text { China-Pakistan Economic } \\
\text { Corridor }\end{array}$ & 2013 & $\begin{array}{l}\text { Both countries jointly declared China-Pakistan } \\
\text { Economic Corridor Long Term Plan } 2030 \text { to } \\
\text { specify the detailed cooperation. }\end{array}$ & $\begin{array}{l}\text { Electricity energy (Geng et } \\
\text { al., 2017), transportation, } \\
\text { port construction, } \\
\text { agriculture, etc. }\end{array}$ \\
\hline 3 & $\begin{array}{l}\text { Bangladesh-China-India-Myanmar } \\
\text { Economic Corridor }\end{array}$ & 2013 & Clear developing plan has not been publicized. & $\begin{array}{l}\text { Construction of ports, gas } \\
\text { pipes. }\end{array}$ \\
\hline 4 & $\begin{array}{l}\text { China-Indochina Peninsula } \\
\text { Economic Corridor }\end{array}$ & 2014 & Clear developing plan has not been publicized. & $\begin{array}{l}\text { Construction of bullet trains, } \\
\text { of roadways. }\end{array}$ \\
\hline 5 & $\begin{array}{l}\text { The China-Mongolia-Russia } \\
\text { Economic Corridor }\end{array}$ & 2014 & $\begin{array}{l}\text { Three countries have declared Planning Outline } \\
\text { of Economic Corridor between China, } \\
\text { Mongolia, and Russia. }\end{array}$ & $\begin{array}{l}\text { Railways and roadways } \\
\text { network, media and } \\
\text { information exchange, } \\
\text { tourism. }\end{array}$ \\
\hline 6 & $\begin{array}{l}\text { China-Central Asia-West Asia } \\
\text { Economic Corridor }\end{array}$ & 2014 & In slow progress & $\begin{array}{l}\text { Energy cooperation, } \\
\text { transportation, nonferrous } \\
\text { metal. }\end{array}$ \\
\hline
\end{tabular}

It is believed that in the past 40 years, China has benefitted quite a lot from the fast development of economy. With the manufacturing ability of Chinese corporations increasing, the domestic market almost reaches its full capacity. There is a great demand for a larger external market. It is, therefore, quite clear that the economic cooperation is the dominant feature of the "Belt \& Road" Initiative.

\section{Chinese Traditional Philosophy and the "B \& R" Initiative}

\section{The Concept of Relations Between Harmony and Diversity}

Chinese philosophy is a big system which influences the people's attitude toward the world, the society, the way of living, and etc. In the "Belt \& Road" Initiative, it is not difficult to find the traces of Chinese traditional philosophy. When people talked about Chinese traditional philosophy, one of the most influential books that they could not ignore is the Analects of Confucius. Mr. Zhao Pu, a Prime Minister of Song Dynasty ever said that "Commanding half of the Analects of Confucius can administer a country" (Luo, 1983, p. 152). So the thought of Confucius is regarded as the representative of Chinese philosophy. According to Confucius, people were divided into two categories: men of virtue and men of meanness. Confucius $(2015$, p. 9) said that men of virtue seek harmony but not uniformity while men of meanness seek uniformity but not harmony. The meaning of this sentence is that the correct way of dealing with relations is to seek harmony even though different parties have a lot of difference. It also means that the wrong way of dealing with relations is that all parties have the same in ideas, attitudes, or behaviors on the surface but there is no harmony among them. In Chinese philosophy, uniformity is not harmony. Uniformity refers to the same or similarity on the surface, but harmony refers to mutual understanding in people's inner mind. Harmony is the top target the whole society should strive for. Only harmony could realize the long peace of a nation. Such philosophical thought could also be found in Chinese guidelines of foreign policies, which is called "Five Principles of Peaceful Coexistence". The five principles are: "mutual respect for territorial integrity and sovereignty, mutual non-aggression,

\footnotetext{
${ }^{3}$ Chinese Government, accessed 26th Dec. 2018, www.gov.cn/xinwen/2018-10/16/content_5331348.htm?_zbs_baidu_bk.
} 
non-interference in each other's internal affairs equality and mutual benefit, peaceful coexistence". The five principles reflect the philosophical thought in Chinese culture, i.e., "diverse but harmonious". In the Analects of Confucius, there was another sentence which stated clearly the importance of harmony. It said "as for the proper rites, harmony is the most valuable" (Confucius, 2015, p. 3).

Another example of the encouragement of "harmony" in Chinese culture could be found in Chinese writing characters. The word "harmony" in Chinese language is the same character with peace. In many Chinese families, especially in the rural areas, people like to put up a calligraphy art in the living room or on the main gate. The art piece usually writes "if a family is in harmony, everything will be successful", or "harmony is the most valuable" as the motto of the family.

\section{The Concept of Relations Between Peace and War}

Chinese people have a quite philosophical approach to understanding the relationship between peace and war. As mentioned above, because of the emphasis on harmony, people are always contemptuous of conflicts, quarrels, noises, fighting, and wars. In a very well-known military book entitled The Methods of Commander Sima, whose author was Mr. Sima Rangju, a commander-in-chief in the 6th century B.C, it contended: "a warlike state, however big it may be, will eventually perish; Although the country is peaceful, but if defense is forgot, it will be in danger" (2018, p.221). Therefore, in Chinese culture, there are many illustrations or descriptions about how to keep good relations with friends, colleagues, neighbors, and even enemies. The sentence "one should not impose on others what he himself does not desire" also from the book that The Analects of Confucius, has become a motto for many Chinese. There are many such sayings which are called as "golden words" in Chinese ancient philosophy. For example: "A far off relative is not as helpful as a near neighbor"; "all the people of the world are brothers". Mencius, another great philosopher after Confucius said that "the one who show respect to others will always receive respect from others". All these philosophical sayings have embedded into Chinese classic tradition and guided Chinese people get along with the people around them.

Historically, China has never invaded other countries. In around 3,000 thousand years, China developed a tributary system. This tributary system was not based on conquer and invasion, but on strength and power. The inner logic of tributary system was that the country itself should first become very wealthy. Just like a train, when a train grows big enough, the small vines will attach itself to the train and people will look for shade and rest under the train. The power and the strength of a country would go up with its wealth. If the country grows strong enough, the neighboring countries will come to the country to seek protection and safeguard. It is because of this reason that China calls itself "Centered Nation". It not only means that it is located in the central land, but also implies that it is centered by other countries. In Chinese ideas, the power comes from the country's strength. In another Chinese martial book entitled The Art of War, the best choice of military strategy is "the supreme art of war is to subdue the enemy without fighting" (2011, p.37). Chinese say that there is no desire for hegemony in Chinese genes.

\section{The Concept of Relations Between State and Family}

When talked about the "Belt \& Road" Initiative, another topic which could not be ignored is the relationship between state and family in Chinese culture. Because of the long and unified history, Chinese people have a special passion for the government and the state. In the world history of 20th century, the ties between the citizens and the government are the most important observation point in nationalism. A 
well-known case is Belgium. Belgium was formed by secession from the United Kingdom of the Netherlands in 1830, whose neutrality and integrity was protected by the Treaty of London 1839. After the Napoleonic Wars, it served as buffer state between France, Prussia (after 1871 the German), and the United Kingdom until World War I. Currently, Belgium is divided between the Flemings in the north and the French-speaking or the German-speaking population in the south. The Flemish population in the north speaks Dutch; the Walloon population in the south speaks French or German. The Brussels population speaks French or Dutch. It is a typical non-nation state. Around the year of 2010, in Belgium, there had been no central government for about 18 months. But it did not influence the normal operation of the country. But such things could never happen in China. The first reason is that Chinese have high recognition of the state. In a Chinese classic poetic collection, Book of Odes, it is stated that "under the whole heaven, every spot is the king's land; to the borders of the land, every individual is the king's servant" (Hills, 2015, p. 623). At the very young age, Chinese teens were taught that he who excels in learning would surely become an official to serve the nation. Chinese word "country" consists of two characters: "State + Home". These two characters combine into one word "country". It could reflect that home could never be separated from state and the vice versa in Chinese culture. For Chinese, one is impossible to have a home if he or she has no country.

Geert Hofstede (2011) argued that power distance is a dimension to mention the difference of culture. This could be discovered by the extent to which Chinese respect the senior, the old, the authority, and the government is much larger than in western cultures. In American society, you could call a very senior person by his given name. But it seems not acceptable in Chinese culture. The juniors normally call the seniors not only by the title together with his/her surname, but also with a very respectful manner. Therefore, in China, if a project or an initiative is not sponsored by the authorities or by the government, it will not be given attention or at least not be regarded as important. "State Affairs Are Great" has developed into an idiom. Reversely, if a government does not launch or sponsor some state or national programs or projects, the government will be regarded as no function or at least not function well by its people. That is why some matters which are usually dealt with by enterprises or by nongovernmental organizations in western countries are usually undertaken or organized by government in China. For example, the Confucius Institute, the number of which has reached 548 till the end of 2018, was regarded as a representative of Chinese government. And some people even looked at the Confucius Institute as a kind of cultural penetration because of its government background. As a matter of fact, any company or nongovernment organization cannot obtain the support from universities or embassies if it is not organized by government, while the Confucius Institute is much like the "Belt and Road" Initiative. Its purpose is only to introduce Chinese culture. The "Belt \& Road" Initiative encountered the same misunderstanding. For many westerners, it is difficult to understand that so many such projects are sponsored by Chinese government. Likewise, for many Chinese, it is difficult to understand that a nation with no government like Belgium could still in operation for almost two years.

\section{Some Concepts to Be Clear}

To have a better understanding of the "Belt \& Road" Initiative, there are some concepts to be clear.

\section{Clash of Civilization vs. Communication of Civilization}

The concept of clash of civilization was raised by American political scientist Samuel P. Huntington. His book The Clash of Civilization and the Remaking of World Order aroused great interest and hot discussion on 
cross-culture issues and kept being the best sellers in many countries. He argued that future wars would be fought not between countries, but between cultures. Even though some scholars, like Francis Fukuyama, doubted that it is not the clash of civilizations but the clash of interests that influences the world order, it reflects that "clash" is the dominant concept in the field of diplomatic relations. Almost at the same period of Huntington, there was a scholar in Northwest University of China, Professor Peng Shuzhi, who raised the idea of communication of civilizations. Professor Peng was a very prominent scholar in world history. He conceived that idea that the civilizations distributing all over the world had the inner drive and energy to communicate and exchange with each other (Peng, 2015, p. 77). The general trend of the world history is communication among civilizations. He proposed that human beings should have the self-consciousness of history to realize that "it is the exchange that makes civilization" instead of that "the exchange brings evil". He even mentioned that in order to keep the civilized communications, the peoples from different cultures should increase their knowledge about each other. This could be seen as the early idea of the "policy co-ordination, facilities connectivity, unimpeded trade, financial integration, people-to-people bonds".

\section{Thucydides Trap vs. New Model of Major Power Relations}

It is believed that the difference in culture played a big role in the different perspective toward the new model of major power relations. What people say, how they say it, what they don't say, especially what they mean by what they say are all deeply affected by culture (Storti, 2007, p. 91).

The concept of Thucydides Trap was come up with by American political scientist Graham Tillett Allison, Jr. in 2017. It held that when a newly rising power emerged, it would definitely cause fear to an established power. Such fear would escalate toward war. Only when the newly rising power completely defeated the established power, the new order could be set up. Thucydides wrote: "What made war inevitable was the growth of Athenian power and the fear which this caused in Sparta" (Allison, 2019). ${ }^{4}$ In another word, when a new power emerges in a region, it will inevitably have a war with the existing power, otherwise, the new power could not take the place of the existing power, or the existing power could not allow the new power exists. The Thucydides Trap is believed the "Jungle Principles" in world politics. Other examples of Thucydides Trap include the start of World War I, the War of the Spanish Succession, the U.S. Civil War, and the Thirty Years War.

Stemmed from the Chinese philosophy, the thought of "harmony but diversity" never brought Chinese into the Thucydides Trap. In modern Chinese diplomacy, a new model of major power relations has been proposed. New model of major power relationship is characterized with mutual respect, mutual benefit, and win-win in dealing with diplomatic relations among the existing powers and newly emerging powers. The term "new model of major power relations" was first used in the US-China Strategic and Economic Dialogue held in May 2012.

Richard Nisbett, a psychological professor in University of Michigan, made a research on the difference of thinking methods between Oriental and Occidental people. He detailed his findings in his book The Geography of Thought: How Asians and Westerners Think Differently...and why. He contended that Oriental people have the habit of dialectical thinking, while the Occidental people analyze with logical thinking (Nisbett, 2003, p. 176). What is dialectical thinking? In such thinking, opposing perspectives are used for contemplating facts,

\footnotetext{
${ }^{4}$ Graham T. Allison, accessed 3rd Jan. 2019,_https://en.wikipedia.org/wiki/.

5 Graham T. Allison, accessed 3rd Jan. 2019, https://en.wikipedia.org/wiki/.
} 
views in the mental process (Peng \& Ames, 2001, p. 3634). The logical thinking is more linear. It explores the preconditions, the background, the process, the consequences, and the reasons. Indeed, in Chinese traditional philosophy, dialectical thinking is often emphasized. A good example is the concept of "Yin" and "Yang", which means the two opposing principles in nature, the former feminine and negative, the latter masculine and positive. Chinese imitate the nature and divide all things into two sides, especially in human bodies and in the medical treatment theories. They believe the nature is composed of the heaven (Yang) and the land (Yin), the sun (Yang) and the moon (Yin), the mountains (Yang) and rivers (Yin), and etc. The time is composed of the day (Yang) and night (Yin), the hot summers (Yang) and the cold winters (Yin). Likewise, in human bodies, there are also two opposing forces inside. If the balance between the opposing sides is disrupted, there will be disorder in the system. So a wise man should know the rules of the balance and be skillful in keeping balance.

In dealing with the foreign relations, Chinese also believe that the order of the world should not be disrupted. To keep the balance, all powers should respect each other, cooperate and benefit from the cooperation. This is the philosophical root of new model of power relations.

\section{Neocolonialism vs. Win-Win Relations}

There is another misconception about the "Belt \& Road" Initiative. Some say that China is pushing neocolonialism by the "Belt \& Road" Initiative. What is neocolonialism? The neocolonialism was first raised by Kwame Nkrumah, the former president of Ghana. It refers to the practice of using capitalism, globalization, and cultural imperialism to influence a developing country in lieu of direct military control (imperialism) or indirect political control (hegemony) (Nkrumah, 1966, p. 74). Nkrumah said that the result of neo-colonialism was that foreign capital was used for the exploitation rather than for the development of the less developed parts of the world. Investment, under neo-colonialism, increased, rather than decreased, the gap between the rich and the poor countries of the world. The struggle against neo-colonialism was not aimed at excluding the capital of the developed world from operating in less developed countries. It was aimed at preventing the financial power of the developed countries being used in such a way as to impoverish the less developed (Nkrumah, 1966, p. 127).

It is not difficult to find the key phrases in the explanation of neocolonialism. The first key phrase is "indirect political control". The precondition of the "Belt \& Road" Initiative is cooperation but not control, whether it is direct or indirect. The aim of cooperation is to realize double win for both the country which supplies the service and products and the country which receives the service and products. Whether it is in the six corridors or in Africa, all the projects or programs in the frame of "Belt \& Road" Initiative were launched on the basis of negotiation and agreement between two parties and the cooperation were carried on based on the voluntariness of both parties.

A second key phrase is "increase rather than decrease the gap between the rich and the poor countries". Firstly, China has been the victim of colonialism for more than 100 years. From 1840s till the founding of People's Republic of China in 1949, China suffered greatly from the colonialism. According to Chinese philosophy, "One should not impose on others what he himself does not desire". Chinese will not subject other nations into colonialism again. As a matter of fact, many countries that have joined into the "Belt \& Road" Initiative have benefitted from the investment, from the cooperation, from the trade, from the service, and etc., whether it is the developing country or the developed country. For example, the bulletin train project in Southeast Asia changed the life of the people there a lot. On the contrary, because of the misconception of the 
"Belt \& Road" Initiative, China lost $\$ 0.8$ billion in Malaysia for the abandonment of bulletin train project by Malaysia government in 2018. Even though China has realized the difficulty in having a good understanding about the "Belt \& Road" Initiative and has been very conscious about the activities abroad, for example, in the peace keeping activities, China insists on that Chinese troops only took part in the activities of UN, but never stationed troops outside China; there needs to have a systematical explanation to the "Belt \& Road" Initiative.

\section{Conclusion}

The "Belt \& Road" Initiative rooted in Chinese traditional philosophy. China has a continuous history longer than 5,000 thousand years. In its long history, China has developed a complex and self-contained philosophical system. This system involves all aspects of lives, some of which are regarded as habits, some as customs, some as experiences, and some as taboos. If a person intends to have a clear view and a correct knowledge of contemporary China, he or she should study well about Chinese history and traditional philosophy. If a country intends to have a good cooperation with China, it also should observe Chinese programs or projects with Chinese philosophy. After a careful study of the relations between the "Belt \& Road" Initiative and Chinese traditional philosophy, three conclusions could be attained.

Firstly, to guarantee an effective communication between the east and the west, both societies should be encouraged to study and know each other. It is evident that there is so much difference between the east and west. If either party only thinks of itself without considering the difference that really exists between them, the misconception will emerge soon. Transcultural studies or cross-cultural studies are necessary for both the east and the west. With the globalization in modern world, any singular person could meet the occasions when cultural exchanges take place. Transcultural or cross-cultural abilities will become dispensable abilities for future human beings.

Secondly, Chinese philosophy is a very important part in the world philosophical family. It is also very prevalent in many Asian countries. It is worthwhile studying Chinese philosophy when studying modern China and East Asia. The core of Chinese philosophy is "harmony but diversity", which also gives birth to many renown ideas such as the balance of "Yin" and "Yang", the relations between peace and war, how to deal with the relations among family members, among colleagues, or even among countries. All these ideas are penetrated in Chinese social customs. If a person has a good command of the Chinese culture and philosophy, he or she will feel much easier to understand Chinese people, Chinese government, Chinese policies, and even Chinese social problems. Chinese people also need to study more about the western cultures and western philosophy. In the past 40 years with the opening up policy in China, western cultures and western philosophy have affected quite a lot of Chinese young generations. Nevertheless, the contact with western culture and western philosophy for many Chinese is too superficial to make them have an accurate understanding of western cultures.

Thirdly, the "Belt \& Road" Initiative is not Chinese "Marshall Plan". China does not seek alliance with other countries by the "Belt \& Road" Initiative. Philosophically, China has no desire to seek for hegemony and there is any necessity for China to look for alliance. Historically, the "Belt \& Road" brought prosperity and wealth to Chinese people. In current peaceful environment, Chinese people look forward to restoring their ever prosperity and wealth with the Silk Road which they believed had ever brought them prosperity and wealth. Economically, in the past 40 years, China has comparatively advanced manufacturing technology and powerful productivity. The domestic market of China becomes smaller and smaller. There are more commercial 
opportunities and financial potentials in the regions along the ancient Silk Road, either on land or on the sea. If China could have cooperation with the nations along the ancient Silk Roads, both China and those nations along the roads will benefit. The win-win consequences will contribute to the prosperity of the whole world.

\section{References}

Chavannes, E.-È. (1913). Documents Sur les Tou-kiueoccidentaux (1st ed.). Beijing: Zhonghua Book Company.

Confucius. (2015). Analects of Confucius. Beijing: Beijing United Publishing Co. Ltd.

Geng, X. Q., Liu, X. C., \& Kang, C. X. (11th Dec. 2017). Lightening the fire of hope in China-Pakistan corridor. China Energy News.

Hills, N. (2015). Book of odes. Beijing: Zhonghua Book Company.

Hofstede, G. (2011). Dimensionalizing cultures: The Hofstede model in context. Online Readings in Psychology and Culture. Retrieved from http://scholarworks.gvsu.edu/orpc/vol2/iss1/8 (accessed 9th Jan. 2019)

Liu, X., \& Zhao, Y. (2018). Old book of Tang history western regions. Beijing: Zhonghua Book Company.

Luo, D. J. (1983). He Lin Yu Lu. Beijing: Zhonghua Book Company.

Nisbett, R. (2003). The geography of thought: How Asians and Westerners think differently...and why. New York: The Free Press, a division of Simon and Schuster, Inc.

Nkrumah, K. (1966). Neocolonialism the last stage of imperialism (1st ed.). New York: International Publishers.

Peng, K., \& Ames, D. (2001). International encyclopedia of the social \& behavioral sciences. Amsterdam, Netherlands: Elsevier. Peng, S. Z. (11th Jun. 2015). Historical perspective of human civilization communication. People's Daily.

Storti, C. (2007). The art of crossing cultures (2nd ed.). Maine: Intercultural Press, Inc.

Von Richthofen, F. (1883). China. Ergebnisseeigener Reisen un daraufgegründeter Studien Vol. I. Berlin: Berlin Dietrich Reimer. 